\title{
Impact of endocrine disruptors on sexuality: A pediatric aspect
}

G Csaba*

Department of Genetics, Cell- and Immunobiology, Semmelweis University, Budapest, Hungary

\begin{abstract}
Endocrine disruptors(EDs) can act and disturb the function of endocrine system during the whole life however, their impact is outstanding during childhood, as the effects in this period could lifelong influence different processes, mainly in the sexual area. The endocrine disruptors can directly influence the development of sexual organs, as teratogens, during the fetal life (cryptorchidism, hypospadias, micropenis), and late (pubertal, adult) sexual events as faulty imprinters (functional teratogens, when the exposure happens perinatally or later). The perinatal period is not the last, when endocrine disruptors can influence the development of sexuality as the system is very sensitive during adolescence and continuously dividing cells can also be imprinted during the whole life. Pubertal hormonal imprinting is also inherited to the progeny generations. The number and amount of EDs are extremely increasing and their importance as inducers of sexual alterations became outstanding. There is not drugs against them (many drugs are EDs themselves) only the information on them and on their effects can help to diminish the danger. It must not forget the DES-catastrophe, when mass vaginal cancers were recognized decades after the exposure to diethylstilbestrol and other serious alterations afterwards in both genders, and must know that EDs are DES-like molecules with very long-time effects.
\end{abstract}

Endocrine disruptors (EDs) are arteficial or natural molecules, which are similar to the steroid hormones or without this, can be bound by nuclear hormone receptors and are able to mimic or influence the effect of physiological hormones introduced to the human organism. These molecules are prepared (and used) by the industry (e.g. bisphenol A ,which is a component of all plastic objects, dental seals or cosmetics ), or utilized by the agrotechnic (as pesticides, herbicides, fungicides etc), are produced by communal tools (e.g. benzpyrene, dioxin) or are present in plants (phytoestrogens, which are consumed by us). A special group of arteficial EDs are the drugs (medicaments) prepared for curing different diseases however, because of their chemical structure behave as EDs. The number and amount of EDs are extremely increasing and their effects are unavoidable in any time of life. However, the most sensitive periods of human life are the fetal, perinatal phases and early childhood, in which their effect influences physiological parameters for life. Because of this, in these periods the effect of EDs is different from the effect in adult age and deserves outstanding consideration.

EDs, being similar to steroid hormones can disturb the normal hormonal functions by binding to steroid hormone receptors, activating the response of the receptor-bearing cell. However, there is also a possibility to block the effect of physiological hormone, occupying its place on the receptor, without activating it. There is also a possibility of inhibition of receptor- or hormone-production. An ED can act on different receptors, provoking an extensive activation[1].

As it was mentioned, the number of EDs is enormous and impossible to study all of them. However, there are some groups which deserve special attention, and some members of them are studied supposing that other (realated) members of the group have similar effects. So bisphenol A (BPA) represents phtalates and phenols, DDT is a representative of pesticides, dioxin and benzpyrene as pollutants of the air, genistein and daidzein as representatives of phytoestrogens and diethylstilbestrol (DES) and vitamin D as representatives of drugs.

\section{Selection of data on prenatal (fetal) ED- effects}

The endocrine disruptors are mostly steroid hormone-like molecules, so they can act as steroid hormones. This means that they are able to disturb the normal development, where hormonal effects are the provocator or influencer of the process. Considering the sexual development they can not influence the determination of sex, as it is done by genes however, the sex ratio between male and female newborns is influenced by them. The normal (male/female) sex ratio in man is $106 / 100$ at birth with the adventage of boys and it was observed in case of an industrial ED, dioxin, that this shifted the adventage to girls in the children of male workers of insecticide factories, without touching female workers $[2,3]$. The explanation of this phenomenon is unknown presently.

There are such malformations, the manifestation of which are strongly influenced by EDs. These are the cryptorchidism, the hypospadias and the length of the penis. The first two common genital birth defects affect 2-9\% or 02-1\% of the male human newborns [4-8]. Measuring the presence of bisphenol A (BPA) and propyl-parabene in the human placenta,, significant association was found between them and the presence of hypospadias and cryptorchidism [9]. Phtalates in general have an outstanding role in the change of semen quality and fertility rates [10]. They are participating as causal factors in the decrease of sperm count[11]. 92\% of newborns with cryptorchidism, hypospadias and/or micropenis presented fetal contamination with EDs (DDT) and their mother (80.36\%) and father (58,63\%) were involved in works with EDs [12].

${ }^{*}$ Correspondence to: György Csaba, Department of Genetics, Cell- and Immunobiology, Semmelweis University, Budapest, Hungary, E-mail: csaba.gyorgy@med.semmelweis-univ.hu

Received: April 05, 2018; Accepted: April 18, 2018; Published: April 26, 2018 
The fungicid vinclozolin inhibit fetal testosterone production and demasculinizes male mice [13]. Phytoestrogens, as genistein causes hypospadias, by altering the expression of genes which are participating in the pathways of morphogenesis [14]. The dietary phytoestrogens (genistein, daidzein) can be demonstrated in $96.2 \%$ of human amniotic fluid tested in the second trimester [15]. Increased serum bioactivity was also demonstrated in case of male pseudohermaphroditism where the mother was exposed to EDs during pregnacy [16]. Coumestrol (a fungal phytoestrogen) and equol (a metabolite of phytoestrogens) also have deleterious effect on gonadal development [17].The effects to gonadal development during the fetal life are transmitted to the progeny generations, epigenetically $[18,19]$.

\section{Perinatal effects}

As long, as the fetus is living in the womb, mostly maternal hormones are regulating its life functions. From this point of view birth is a milestone of the life, as after it the hormones produced by the infant command the life functions, accepting the signals and directing the responses. For this process the setting of receptor-hormone coupling is needed which does happen in case of the first encounter between the developing receptor and the infant's hormones. This provokes the physiological hormonal imprinting, which is absolutely needed for the normal function of receptor-hormone connection. This connection which is established by the imprinting is long-lasting and determines the binding capacity of receptor for life $[20,21]$. However, though the binding of receptor is almost specific for the hormone, perinatally it can be misdirected by hormone analogons [22], related or synthetic hormones, members of a hormone family, hormone-like vitamins [23,24], drugs, or environmental pollutants, as the endocrine disruptors. This leads to faulty hormonal imprinting, the effect of which is also prolonged for life and could cause differences in hormone binding and sexual hormone levels [25], consequently inclination to diseases or manifest diseases (e.g. tumours). As sexual functions are also dependent on hormones, faulty perinatal hormonal imprinting can cause different alterations in sexual behavior [26], in fertility etc. This means that the perinatal effect causes late manifestation as was in the case of diethylstilbestrol (DES), (it is worth mentioning that DES was prescribed for avoiding spontaneous abortions in case of endangered pregnancies, but later without prescription for more beautiful babies) when decades were passed between the exposition (of the drug) and the manifestation of diseases (clear cell vaginal carcinoma, behavioral sexual differences, etc)[27] . A special property of perinatal imprinting is the low dose of imprinter and the short exposition: only a single dose of imprinter is enough for the provocation of imprinting. An other very important property is the heritabilty of imprinting [28] by an epigenetic route [29]. While in the case of fetal ED exposures the interrelation between the long lasting exposure and anatomical malformation in men is clear, in the case of hormonal imprinting in men the interrelation between the single encounter between the receptor and the faulty imprinter hardly justifiable. Considering this, there are only animal experiments which justifies the hormonal imprinting, except the DES-case however, in the time of DES-catastrophe the concept of hormonal imprinting was not known, consequently the explanation of it by imprinting is subsequent.

The polycyclic hydrocarbon, benzpyrene is present in different concentrations in the air, polluting first of all the urban air. It is a very important and hardly avoidable endocrine disruptor, acting to human beings from birth to death. The perinatal exposure in rat experiments caused a profound increase in sexual activity of male rats, while that of females a dramatic decrease was observed [30]. The binding capacity of uterine estrogen receptors were also significantly decreased [31]. The effect of imprinting was transmitted to the progenies [32].

One of the most dangerous EDs, is bisphenol A (BPA). In male rats a depotentiation of sexual behavior was observed after perinatal exposure, while in females a potentiation [33]. Studying two sexually dimorphic regions of the brain the faulty imprinting with BPA altered sex-specific hypothalamic morphology [34,35]. Phtalate/adipate esters caused decreased copulatory behavior in males and also decreased lordosis quotient [36]. The demasculinization of males was outstanding.

Vinclozolin administered perinatally reduced erections of adult male rabbits $[37,38]$. The faulty imprinting effect of this fungicide was manifested transgenerationally when male infertility was also observed [40].The phytoestrogen, genistein given perinatally negatively influenced sperm and testosterone production and aggressivity decreased while defensive reactions increased in adult age [41]. Genistein also increases female and male rat's sexual activity [42]. Daidzein, an other soy isoflavone adversely affected penile erection in adulthood [43].

Lipid-soluble vitamins, as vitamin A and Vitamin D are not vitamins, but hormones (exohormones) which are bound by the members of nuclear hormone recepor family and can activate them [44]. Sexual activity of adult rats treated neonatally with vitamin A or D3 $[45,46]$, as well, as with vitamins $\mathrm{E}$ and $\mathrm{K}$, were depressed or completely inhibited in adult age $[47,48]$

\section{Impact of endocrine disruptors on the onset of puberty (selection of data)}

The time of puberty which is showed by menarche and thelarche in girls and penil erection and ejaculation in boys is determined by the individual endocrine system however, it has a mean which can be calculated. This mean (the secular trend of European and American youth) is becaming earlier related to the last centuries (96). The precocious puberty is more frequent and the change is supposed to be due of steroid- hormone like compounds in the human environment, in foods and waters [49-60].

The urinary BPA levels in girls having central precocious puberty (CPP) was higher than normal [61-63], and serum BPA concentration was also higher in girls with thelarche, aged 4 month to 2 year [64]. Peripheral precocious puberty was observed in 4-month-old girl,(whose father had a dramatic decrease of libido) and pesticides were found in the serum [65]. The serum genistein and daidzein concentrations were also higher in Korean girls having precocious puberty [66]. In premature breast development (thelarche, younger than 8 years) phtalate esters were higher in the serum $[67,68]$. The incidence of precocious puberty of children migrating into Belgium is higher with relation to their plasma level of DDT [69]. Different EDs and isoflavones were higher in the plasma of precocious puberty patients [70].

Higher serum testosterone concentrations were associated with higher phtalate and BPA concentrations in maternal urine during different phases of pregnacy [71].

\section{Data on the effects during puberty}

Tamoxifen treatment for $5+2$ days at adolescent age dramatically reduced the sexual activity of rats (from 40 to $10 \%$ immediately after treatments and 4-6 weeks after treatments [72]. Adolescent rats (sixth and sevent weeks after birth) were treated with retinol or retinoic acid, and serum testosterone and progesterone levels were measured in the 
4th month. Retinol diminished testosterone level and was neutral to progesterone level. Retinoic acid decreased testosterone level and elevated progesterone level [73]. Pubertal benzpyrene imprinting caused a durable decrease in females' estrogen receptor density [74]. The effect of pubertal imprinting is inherited to the progeny generations epigenetically $[74,75]$ similar to the inheritance of perinatal hormonal imprinting [76].

\section{Conclusions}

The above mentoned data clearly show that the endocrine disruptors strongly influence the sexuality in man and in animal experiments. There is a possibility of direct effects, when the hormonal exposure is teratogenic (if it is during the fetal life), which is manifested first of all in cryptorchidism or hypospadias or micropenis however an other possibility is the late effect, when the perinatal exposure (faulty hormonal impinting) does not provoke malformation however, later, during adolescence or in adult age pathological alterations appear, as early onset of puberty, obesity or changes in sexual capacity and behavior (functional teratogenicity). These alterations also can be observed in the progeny generations, which means that the effect of imprinting is inherited. In this case the inheritance does not mean a regular change of genetic material, but an inheritance by epigenetic route, which means the alteration in the expression of genes by the change of methylation of DNA or histones, which influences gene expression . Endocrine disruptors, as hormone-like materials are not neutral introduced into adults however, childhood exposure has deeper and wider effect as such structures are touched which are able to be transformed or are able to influence other structures. This means that childhood exposures to endocrine disruptors deserves outstanding attention. and not only the acute effects can be observed but also the presumable or not foreseeble, but possible consequences are taking into consideration. In the evaluation maternal and paternal transmission of ED contamination must be discriminated, as paternal risk factors are more transmissible [76].

There are such EDs, which are known and can be avoided and there are others, which are hidden in the air, the drinking water or food etc. Medicaments, as was the DES or are at present, as vitamin A or D, the fat soluble vitamins which are hormones really[44], can be avoided. Can not be avoided benzpyrene or dioxin in the urban air, pesticides, herbicides, insecticides or contraceptive pill wast products in drinking water. And which are hardly avoidable are the phytoestrogens, components of soy (genistein and daidzein), which are present in clear or hidden forms in our food (soy formula as baby food, sausages, ice cream etc) which are consumed sometimes in extreme amount during childhood or by the nursing mother. Which can not be avoided it must be accepted however, we have to know that these molecules can be responsible for sexual alterations, inclination or manifestation of different diseases during late childhood and adult age.

Soy bean isofalvones are the most suspected EDs in the provocation of early onset of puberty [77]. Soy is used in different forms as food in Asian countries where the onset of puberty (menarche, thelarche) is different from that of European countries. However, in the last century soy foods are more frequently used in Europe and in the US than it was before, even than in Asian countries. Though they have some beneficial effects, their adverse effects could be dominant [78]. This alone would be enough for the increase of the number of precocious puberties. However, this is supplemented by the enormous amount of industrial and communal EDs. Precocious puberty used to be associated with other alterations, as e.g. malignant tumours, sexual disturbances, etc.
This means that the manifestation of precocious puberty is a part of the general provocation of developmental potencies by the ED.

The long-lasting effect of EDs is not finished perinatally as there are periods of life, when the sensitivity to endogeneous or exogeneous imprinters -such as EDs- is also high. Adolescence is the main late period and as it was shown, in this period hormone-like factors can seriously influence sexuality for life at brain level, as well as in the level of sexual hormone receptors in general .

It seems to be very interesting and important the epigenetic inheritance of pubertal imprinting. It can be explained by the fact that during adolescence continously dividing (differentiating) cells can be imprinted and the male germ cells (spermatogonia) are also dividing.

Childhood obesity is very frequent in the countries where ED exposure is also frequent during childhood. The interrelation between the obesity and EDs seems to be clear [79-82] however, other factors (e.g. hyperfeeding) also can not be disclosed. Obesity is a part of the metabolic syndrome however, the interrelation between EDs and this latter is not completely cleared, but EDs are suspected in the dramatic increase of type 2 diabetes, especially in childhood [83-85].

The data mentioned above clearly show that the effect of endocrine disruptors is wide and very important areas are touched by them. The situation is aggravated by the cooperation of disruptor effects and by the transgenerational inheritance of inclinations caused by malformation (cryptorchidism etc) provoking fetal effects or functional teratogen faulty perinatal hormonal imprinting [74,86,87]. The cooperation can be resulted in such forms of diseases which can not be classified to the traditional ones and complicated by the long time between the disruptor exposure (in different periods of life by different cooperating chemicals) and the manifestation of disease, which hides the connection. The inheritance not only disturbs the health of the next generations but the disruptors of the future will effect on individuals sensitized to endocrine disruptors of the present time.

In the case of DES about two decades passed when the alterations of the sexual area appeared and the relation between the vaginal cancer and DES on the basis of fetal/perinatal exposure has been cleared. In the case of endocrine disruptors the recognition of interrelations will be more complicated, as not one substance can be suspected, but numerous molecules with different origin [88]. There is no time to pass without doing something against their effects.

There are not antidotes to endocrine disruptors. However, many of them can be avoided, and doctors must attend to not prescribe them, if they can be avoided. In addition it must call the parents' attention to the dangers of EDs, which is unknown by them, and hormone-like vitamins and soy foods can be bought without prescription. The first step in this fight against EDs is the convincing of medical doctors (the author hopes that it is done by this review), who try to avoid the prescription of EDs and transmit the informations to the parents after that.

\section{References}

1. Neubert D (2002) Reproductive toxicology: the science today. Teratog Carcinog Mutagen 22: 159-174. [Crossref]

2. Latini G, Del Vecchio A, Massaro M, Verrotti A, De Felice C (2006) Phtalate exposure and male infertility. Toxicology 226: 90-98. [Crossref]

3. Mackenzie CA, Lockridge A, Keith M (2005) Declining sex ratio in a first nation Community. Environ Health Perspect 113: 1295-1298. [Crossref]

4. Bouty A, Ayers KL, Pask A, Heloury Y, Sinclair AH (2015) The genetic and environmental factors underlying hypospadias. Sex Dev 9: 239-259. [Crossref] 
5. Toppari J, Virtanen HE, Main KM, Skakkebaek NE (2010) Cryptorchidism and hypospadias as sign of testicular dysgenesis syndrome (TDS): environmental connection. Birth Defects Res A Clin Mol Teratol 88: 910-919. [Crossref]

6. Barthold JS, Reinhardt S, Thorup J (2016) Genetic, maternal and environmental risk factors for cryptorchidism: an update. Eur J Pediatr Surg 26: 399-408. [Crossref]

7. Estor Sastre B, Bragagnini Rodriguez P, Fernandez Atuan R, Delgado Alvira R, Rihuete Heras MA, et al. (2015) Endocrine disrupting chemicals exposure and other parental factors in hypospadias and cryptorchidism etiology. Cir Pediatr 28: 128-132. [Crossref]

8. Main KM, Skakkebaek NE, Virtanen HE, Toppari J (2010) Genital anomalies in boys and the environment. Best Pract Res Clin Endocrinol Metab 24: 279-289. [Crossref]

9. Fernandez MF, Arrebola JP, Jiménez-Diaz I, Sáenz JM, Molin-Molina JM, et al. (2016) Bisphenol A and other phenols in human placenta from children with cryptorchidism or hypospadias. Reprod Toxicol 59: 89-95. [Crossref]

10. Fenichel P, Chevalier N, Brucker-Davis F (2013) Bisphenol A: an endocrine and metabolic disruptor. Ann Endocrinol (Paris) 74: 211-220. [Crossref]

11. Habert R, Muczynski W, Lehraiki A, Lambrot R, Lécureuil C, et al. (2009) Adverse effects of endocrine disruptors on the foetel testis development: focus on phtalates. Folia Histochem Cytobiol 47: S67-74. [Crossref]

12. Gaspari L, Sampaio DR, Paris F, Audran F, Orsini M, et al. (2012) High prevalence of micropenis in 2710 male newborns from an intensive-use pesticide area of Northeastern Brazil. Int J Androl 35: 253-264. [Crossref]

13. Gray LE, Ostby J, Furr J, Price M, Veeramachaneni DN, et al. (2000) Perinatal exposure to the phtalates DEHP, BBP, and DINP, but not DEP, DMP, or DOTP, alters sexual differentiation of the male rat. Toxicol Sci 58: 350-365. [Crossref]

14. Ross AE, Marchionni L, Phillips TM, Miller RM, Hurley PJ, et al. (2011) Molecular effects of genistein on male urethral development. J Urol 185: 1894-1898. [Crossref]

15. Foster WG, Chan S, Platt L, Hughes CL jr (2002) Detection of phytoestrogens in samples of second trimester human amniotic fluid. Toxicol Lett 129: 199-205. [Crossref]

16. Paris F, Jeandel C, Servant N, Sultan C (2006) Increased serum estrogenic bioactivity in three male newborns with ambiguous genitalia: a potential consequence of prenatal exposure to environmental disruptors. Environ Res 100: 39-43. [Crossref]

17. Medlock KL, Branham WS, Sheehan DM (1995) Effects of coumestrol and equol on the developing reproductive tract of the rat. Proc Soc Exp Biol Med 208: 67-71. [Crossref]

18. Anway MD, Cupp AS, Uzumcu M, Skinner MK (2005) Epigenetic transgenerational actions of endocrine disruptors and male fertility. Science 308: 1466-1469. [Crossref]

19. Chen J, Wu S, Wen S, Shen L, Peng J, et al. (2015) The mechanism of environmental endocrine disruptors (DEHP) induces epigenetic transgenerational inheritance of cryptorchidism. PLOS one 10: e0126403. [Crossref]

20. Csaba G (1980) Phylogeny and ontogeny of hormone receptors: the selection theory of receptor formation and hormonal imprinting. Biol Rev Camb Philos Soc 55: 47-63. [Crossref]

21. Csaba G (2000) Hormonal imprinting: its role during the evolution and development of hormones and receptors. Cell Biol Int 24: 407-414. [Crossref]

22. Csaba G, Inczefi-Gonda Á (2000) Effect of neonatal treatment with mifepristone or tamoxifen on the binding capacity of the thymic glucocorticoid or uterine estrogen receptor of adult rats: data on the mechanism of hormonal imprinting. Life Sci 67 : 2531-2537. [Crossref]

23. Csaba G, Inczefi-Gonda Á, Dobozy O (1986) Hormonal imprinting by steroids: a single neonatal treatment with diethylstilbestrol or allylestrenol gives rise to a lasting decrease in the number of rat uterine receptors. Acta Physiol Hung 67: 207-212. [Crossref]

24. Gaál A, Csaba G (1998) Effect of retinoid (vitamin A or retinoic acid) treatment (hormonal imprinting) through breastmilk on the glucocorticoid receptor and estrogen receptor binding capacity of the adult rat offspring. Hum Exp Toxicol 17: 560-563. [Crossref]

25. Pap E, Csaba G (1995) Effect of prenatal allylestrenol treatment (hormonal imprinting) on the serum testosterone and progesterone level in adult rats. Gen Pharmacol 26: 365-367. [Crossref]

26. Csaba G, Karabélyos C (2001) The effect of a single neonatal treatment (hormona imprinting) with the antihormones, tamoxifen and mifepristone on the sexual behavior of adult rats. Pharmacol Res 43: 531-534. [Crossref]

27. Schrager S, Potter BE (2004) Diethystilbestrol exposure. Am Pham Physician 69: 2395-2400.[Crossref]
28. Csaba G (2016) The faulty perinatal hormonal imprinting as functional teratogen. Curr Pediatr Rev 12: 222-229. [Crossref]

29. Csaba G (2011) The biological basis and clinical significance of hormonal imprinting, an epigenetic process. Clin Epigenetics 2: 187-196. [Crossref]

30. Csaba G, Karabélyos C, Dalló J (1993) Fetal and neonatal action of a polycyclic hydrocarbon (benzpyrene) or a synthetic steroid hormone (allylestrenol) as reflected by the sexual behaviour of adult rats. J Dev Physiol 19: 67-70. [Crossref]

31. Csaba G, Inczefi-Gonda Á (1993) Uterus estrogen receptors' binding capacity is reduced in rat if exposed by benzpyrene neonatally. J Dev Physiol 19: 217-219. [Crossref]

32. Csaba G, Karabélyos C (1997) Transgenerational effect of a single neonatal benzpyrene treatment (imprinting) on the sexual behavior of adult female rats. Hum Exp Toxicol 16 : 553-556. [Crossref]

33. Farabollini F,Porrini S, Della Seta D, Bianchi F, Dessi-Fulgheri F (2002) Effects of perinatal exposure to bisphenol A on sociosexual behavior of female and male rats Environ Health Perspect 110: 409-414. [Crossref]

34. Rubin BS, Lenkowski JR, Schaeberle CM, Vandenberg LN, Ronsheim PM, et al. (2006) Evidence of altered brain sexual differentiation in mice exposed perinatally to low, environmentally relevant levels of bisphenol A. Endocrinology 147: 3681-3691. [Crossref]

35. McCaffrey KA, Jones B, Mabrey N, Weiss B, Swan SH, et al. (2013) Sex specific impact of perinatal bisphenol A (BPA) exposure over a range of orally administered doses on rat hypothalamic sexual differentiation. Neurotoxicology 36: 55-62. [Crossref]

36. Lee HC, Yamanouchi K, Nishihara M (2006) Effects of perinatal exposure to phtalate/ adipate esters on hypothalamic gene expression and sexual behavior in rats. $J$ Reprod Dev 52: 343-352. [Crossref]

37. Colbert NK, Pelletier NC, Cote JM, Concannon JB, Jurdak NA, et al. (20005) Perinata exposure to low levels of the environmental antiandrogen vinclozolin alters sexdifferentiated social play and sexual behaviors in the rat. Environ Health Perspect 113: 700-707. [Crossref]

38. Veermachaneni DN, Palmer JS, Amann RP, Pau KY (2007) Sequelae in male rabbits following developmental exposure to p,p'- DDT or a mixture of p,p'-DDT and vinclozolin: cryptorchidism, germ cell atypia and sexual dysfunction. Reprod Toxicol 23: 353-365.

39. Walker DM, Gore AC (2011) Transgenerational neuroendocrine disruption of reproduction. Nat Rev Endocrinol 7: 197-207. [Crossref]

40. Guerrero-Bosagna CM, Skinner MK (2009) Epigenetic transgenerational effects of endocrine disruptors on male reproduction. Semin Reprod Med 27: 403-408. [Crossref]

41. Wisniewski AB, Cernetich A, Gearhart JP, Klein SL (2005) Perinatal exposure to genistein alters reproductive development and aggressive behavior in male mice. Phsiol Behav 84: 327-334. [Crossref]

42. Csaba G, Karabélyos C (2002) Effect of single neonatal treatment with the soy bean phytosteroid genistein on the sexual behavior of adult rats. Acta Physiol Hung 89: 463470. [Crossref]

43. Pan L, Xia X, Feng Y, Jiang C, Cui Y, et al. (2008) Exposure of juvenile rats to the phytoestrogen daidzein impairs erectile function in a dose-related manner in adulthood. $J$ Androl 29: 55-62. [Crossref]

44. Csaba G (2017) Vitamin-caused faulty perinatal hormonal imprinting and its consequences in adult age. Physiol Int 104: 217-225. [Crossref]

45. Csaba G, Gaál A (1997) Effect of perinatal vitamin A or retinoic acid treatmen (hormonal imprinting) on the sexual behavior of adult rats. Hum Exp Toxicol 16: 193197. [Crossref]

46. Mirzahosseini S, Karabályos C, Dobozy O, Csaba G (1996) Changes in sexual behavior of adult male and femele rats neonatally treated with vitamin D3. Hum Exp Toxicol 15: 573-576. [Crossref]

47. Csaba G (2016) Faulty perinatal hormonal imprinting caused by exogeneous vitamin D-dangers and problems. Austin J Nutr Food Sci 4: 1075-1079. [Crossref]

48. Csaba G, Karabélyos C (2000) Influence of a single treatment with vitamin E or K (hormonal imprinting) of neonatal rats on the sexual behavior of adults. Acta Physiol Hung 87: 25-30. [Crossref]

49. Ozen S, Darcan S, Bayindir P, Karasulu E, Simsek DG, et al. (2012) Effects of pesticides used in agriculture on the development of precocious puberty. Environ Monit Assess 184: 4223-4232. [Crossref]

50. Massart F, Parrino R, Seppia P, Fedderico G, Saggese G (2006) How do environmental estrogen disruptors induce precocious puberty. Minerva Pediatr 58: 247-254. [Crossref] 
51. Roy JR, Chakraborty S, Chakraborty TR (2009) Estrogen-like endocrine disrupting chemicals affecting puberty in humans - a review. Med Sci Monit 15: RA137- 145. [Crossref]

52. Ozen S, Darcan S (2011) Effects of environmental endocrine disruptors on pubertal development. J Clin Res Pediatr Endocrinol 3: 1-6. [Crossref]

53. Charlier C1 (2006) Effects of environmental pollutants on hormone disturbances. Bull Mem Acad R Med Belg 161: 116-124. [Crossref]

54. Patisaul HB (2013) Effects of environmental endocrine disruptors and phytoestrogens on the kisspeptin system. Adv Exp Med Biol 784: 455-479. [Crossref]

55. Leonardi A, Cofini M, Rigante D, Lucchetti L, Cipolla C, et al. (2017) The Effect of Bisphenol A on Puberty: A Critical Review of the Medical Literature. Int J Environ Res Public Health 14. [Crossref]

56. Konieczna A, Rutkowska A, RachoÅD (2015) Health risk of exposure to Bisphenol A (BPA). Rocz Panstw Zakl Hig 66: 5-11. [Crossref]

57. Ozen S, Darcan S (2011) Effects of environmental endocrine disruptors on pubertal development. J Clin Res Pediatr Endocrinol 3: 1-6. [Crossref]

58. Parent AS, Franssen D, Fudvoye J, Pinson A, Bourguignon JP (2016) Current changes in pubertal timing: revised version in relation with environmental factors including endocrine disruptors. Endocr Dev 2016; 29: 174-184. [Crossref]

59. Schoeters G, Den Hond E, Dhooge W, van Larebeke N, Leijs M (2008) Endocrine disruptors and abnormalities of pubertal development. Basic Clin Pharmacol Toxicol 102: 168-175. [Crossref]

60. Teilmann G; Juul A, Skakkebaek NE, Toppari J (2002) Putative effectsof endocrine disrupters on pubertal development in human. Best Pract Res Clin Endocrinol Metab 16: 105-121. [Crossref]

61. Durmaz E, Asci A, Erkekoglu P, Akcurin S, Gümüsel BK, et al. (2014) Urinary bisphenol levels in girls with idiopathic central precocious puberty. J Clin Res Pediatr Endocrinol 6: 16-21. [Crossref]

62. Bulus AD, Asci A, Erkekoglu P, Balci A, Andiran N, et al. (2016) The evaluation of possible role of endocrine disruptors in central and pripheral precocious puberty. Toxicol Mech Methods 26:493-500. [Crossref]

63. Supornchilchai V, Jantarat C, Nosoognoen W, Pornkunwilai S, Wacharasindhu S, et al. (2016) Increased levels of bisphenol A (BPA) in Thai girls with precocious puberty. $J$ Pediatr Endocrinol Metab 29: 1233-1239. [Crossref]

64. Chen LH, Shi JR, Fang YL, Liang L, Chen WQ, et al. (2015) Serum bisphenol A concentration and premature thelarche in female infants aged 4-month to 2 year. Indian J Pediatr 82: 221-224. [Crossref]

65. Gaspari L, Paris F, Jeandel C, Sultan C (2011) Peripheral precocious puberty in a 4-month-old girl: role of pesticides? Gynecol Endocrinol 27: 721-724. [Crossref]

66. Kim J (2011) High serum isoflavone concentrations are associatwed with the risk of precocious puberty in Korean girls. Clin Endocrinol (Oxf) 75: 831-835. [Crossref]

67. Colon I, Caro D, Bourdony CJ, Rosario O (2000) Identification of phtalate esters in the serum of young Puerto Rican girls with premature breast development. Environ Health Perspect 108: 895-900. [Crossref]

68. Fortes EM, Malerba MI, Luchini PD, Sugawara EK, Sumodjo L, et al. (2007) High intake of phytoestrogens and precocious thelarche: case report with a possible correlation. Arg Bras Endocrinol Metabol 51: 500-503. [Crossref]

69. Parent AS, Rasier G, Gerard A, Heger S, Roth C, et al. (2005) Early onset of puberty: tracking genetic and environmental factors. Horm Res 64: 41-47. [Crossref]
70. Yum T, Lee S, Kim Y (2013) Association between precocious puberty and some endocrine disruptors in human plasma. J Environ Sci Health Tox Hazard Subst Environ Eng 48: 912-917. [Crossref]

71. Watkins DJ, Sánchez BN, Téllez-Rojo MM, Lee JM, Mercado-Garcia A, et al. (2017) Phtalate and bisphenol A exposure during in utero windows of susceptibility in relation to reproductive hormones and pubertal development in girls. Environ Res 159: 143151. [Crossref]

72. Csaba G, Karabélyos C, Inczefi-Gonda Á (2001) Effect of tamoxifen treatment at adolescent age on the sexual behaviour and steroid hormone receptor binding of adult female rats. Acta Physiol Hung 88: 131-137. [Crossref]

73. Gaál A, Csaba G (1998) Testosterone and progesterone level alterations in the adult rat after retinoid (retinol or retinoic acid) treatment (imprinting) in neonatal or adolescent age. Horm Metab Res 30: 487-489. [Crossref]

74. Csaba G, Inczefi-Gonda Á (1999) Direct and transgenerational effect of benzpyrene treatment at adolescent age on the uterine estrogen receptor and thymic glucocorticoid receptor of the adult rat. Acta Physiol Hung 86: 29-36. [Crossref]

75. Perera F, Herbstman J (2011) Prenatal environmental exposures, epigenetics and disease. Reprod Toxicol 31: 363-373. [Crossref]

76. Mao Z, Xia W, Chang H, Huo W, Li Y, et al. (2015) BPA exposure in early life alter Igf2 epigenetic status in sperm and induces pancreatic impairment in rat offspring. Toxicol Lett 238: 30-38. [Crossref]

77. Marks KJ, Hartman TJ, Taylor EV, Rybak ME, Northstone K, et al. (2017) Exposure to phytoestrogens in utero and age at menarche in a contemporary British cohort. Environ Res 155: 287-293. [Crossref]

78. Patisaul HB, Jefferson W (2010) The pros and cons of phytoestrogens. Front Neuroendocrinol 31: 400-419. [Crossref]

79. Hatch EE, Nelson JW, Stahlhut RW, Webster TF (2010) Association of endocrine disruptors and obesity: perspectives from epidemiological studies. Int J Androl 33: 324-332. [Crossref]

80. Li DK, Miao M, Zhou Z, Wu C, Shi H, et al. (2013) Urine bisphenol-A level in relation to obesity and overweight in school-age children. Plos one 8: e65399. [Crossref]

81. Biro FM, Greenspan LC, Galvez MP (2012) Puberty in girls of the 21st century. $J$ Pediatr Adolesc Gynecol 25: 289-294. [Crossref]

82. Choi J, Eom J, Kim J, Lee S, Kim Y (2014) Association between some endocrinedisrupting chemicals and childhood obesity in biological samples of young girls: a cross-sectional study. Environ Toxicol Pharmacol 38: 51-57. [Crossref]

83. Iughetti L, Lucaccioni L, Predieri B (2015) Childhood obesity and environmental pollutants: a dual relationship. Acta Biomed 27: 5-16. [Crossref]

84. Alonso-Magdalena P, Quesada I, Nadal A (2011) Endocrine disruptors in the etiology of type 2 diabetes mellitus. Nat Rev Endocrinol 7: 346-353. [Crossref]

85. Tang-Péronard JL, Andersen HR, Jensen TK, Heitmann BL (2011) Endocrinedisrupting chemicals and obesity development in humans: a review. Obes Rev 12: 622636. [Crossref]

86. Csaba G (2014) Transgenerational effects of perinatal hormonal imprinting. In: Transgenerational epigenetics, ed. T. Tollefsbol. Academic Press New York.

87. Walker DM, Gore AC (2011) Transgenerational neuroendocrine disruption of reproduction. Nat Rev Endocrinol 7: 197-207. [Crossref]

88. Rutkowska A, Rachon D, Milewicz A, Ruchala M, Bolanowski M, et al. (2015) Polis Society of Endocrinology Position statement on endocrine disrupting chemicals (EDCs). Endokrynol Pol 66: 276-281. [Crossref]

Copyright: (C2018 Csaba G. This is an open-access article distributed under the terms of the Creative Commons Attribution License, which permits unrestricted use, distribution, and reproduction in any medium, provided the original author and source are credited. 